\title{
Classification of the Major Soils of Hungary and their Correlation with the World Reference Base for Soil Resources (WRB)
}

\author{
E. MICHÉLI, M. FUCHS, P. HEGYMEGI and P. STEFANOVITS \\ Szent István University, Department of Soil Science and Agricultural Chemistry, \\ Gödöllö (Hungary)
}

\section{Introduction}

Soils of Hungary are very diverse due to the array of soil forming factors in the different geographic areas of the Carpathian Basin. Hungary is situated between the northern latitude of $45^{\circ} 45^{\prime}$ and $48^{\circ} 35^{\prime}$ and between the longitude of $16^{\circ} 07^{\prime}$ and $22^{\circ} 54^{\prime}$ east. The 93,030 square $\mathrm{km}$ territory of Hungary is about $1 \%$ of Europe. The elevation in more than half of the country is less than $200 \mathrm{~m}$, and only $2 \%$ is above $400 \mathrm{~m}$ above sea level. Most of the current topography is a result of neo-tectonic activities and peri-glacial processes during the quaternary period. The low elevation areas are mainly covered by aeolian and alluvial materials and the higher areas are derived from older sedimentary and volcanic rocks.

The mean annual temperature is $10{ }^{\circ} \mathrm{C}$ for most of the country and the mean annual precipitation is between 500 and $800 \mathrm{~mm}$. Precipitation tends to be greater in the higher elevation areas of the western and the northeastern sections and lower on the Hungarian Great Plain in the central part of the country.

In the regions of higher elevations, where precipitation exceeds evapotranspiration, the dominant downward moisture movement and mainly forest vegetation conditioned the development of leached forest soils mostly with textural B horizons. On steeper slopes with highly erosive parent materials shallow soils formed. In the lowland areas, primarily loess, some alluvial material and aeolian sand are the dominant parent material. On stable loess surfaces steppe soils with deep dark surface horizons and high base status formed. In some parts of the plains where the groundwater is close to the surface hydromorphic soils are typical with or without the influence of soluble salts.

The objective of this paper is to give an overview of the soils of Hungary, a brief description of their genesis, properties, and classification and to demonstrate their correlation with the World Reference Base for Soil Resources (WRB).

Correspondence to: ERIKA MICHÉLI, Szent István University, Department of Soil Science and Agricultural Chemistry, H-2103 Gödöllö, Páter Károly út 1. Hungary. E-mail: micheli.erika@mkk.szie.hu 


\section{Materials and Methods}

The current Hungarian Soil Classification System (HSCS) was developed in the $1960 \mathrm{~s}$, based on the genetic principles of Dokuchaev. The central unit is the soil type grouping soils that were believed to have developed under similar soil forming factors and processes. The major soil types are the highest category that group soils based on climatic, geographical and genetic bases. Subtypes and varieties are distinguished according to the assumed dominance of soil forming processes and observable/measurable morphogenetic properties. This paper discusses the soils of Hungary and their correlation at the major soil type and soil type level. The description of the units of the HSCS (STEFANOVITS, 1963; SzABOLCS, 1966), the manual of the WRB (FAO/ISRIC/ISSS, 1998) and field experience were used for the description of the soil units and their correlation in the WRB. It should be noted that limits and definitions are different or missing in the HSCS as compared to the WRB well-defined diagnostic definitions. A further difficulty is that some of the analytical procedures for soil properties differ from those suggested by the FAO manual (VAN REEUWIJK, 1995). Hence the correlations given in Table 2 are only best approximations. When specific pedons are of interest, morphological descriptions and laboratory data are required for correct WRB correlations.

The World Reference Base for Soil Resources (WRB) is the global correlation scheme for soil classification and international communication accepted by the International Union of Soil Sciences (IUSS) in 1998. The European Commission also selected the WRB as the correlation scheme for harmonized soil maps and databases for Europe. The WRB is based on diagnostic approach. Thirty Reference Groups (RG) are defined by a key based on the presence, sequence or exclusion of diagnostic horizons, properties and/or materials. The lower levels are defined by qualifiers added to the names of the reference soil groups for specific soil characteristics. A simplified key of the WRB is presented in Table 1.

\section{Summary Description and Discussion of the Major Soils of Hungary}

On the highest - Major Soil Type - level, 9 categories are distinguished: skeletal soils, shallow soils influenced by the parent material, brown forest soils, chernozems, salt affected soils, meadow soils, peat soils, soils of swampy forests, and soils of alluvial and slope sediments.

\section{Skeletal soils}

These are weakly developed, shallow mineral soils in which some constraints limit soil formation. This major soil type combines a broad range of soils from those with a few cm of fine earth over hard rock to deeper sandy soils with a humus layer up to $30 \mathrm{~cm}$. Therefore correlation of skeletal soils with the WRB is best done at the next lower category. 
Stony skeletal soils develop in stony and rocky materials and have little or no evidence of soil formation. They have little development of pedogenic horizons due to steep slopes, topographic position and/or the resistant nature of the parent material. They correlate with Lithic Leptosols in the WRB.

The gravelly skeletal soils develop in gravelly, mainly alluvial sediments. Based on the percentage of fine earth in the profiles they correlate with Leptosols or Cambisols.

Barren earth soils are rather different from other members of the major type as they develop on weathered, soft parent material. Their limited development correlates best with Regosols or Calcisols.

In sandy areas of Hungary soil formation is limited by low weathering rate, low water holding capacity and frequent erosion of the surface. Where vegetation has not developed shifting sands dominate, where vegetation has stabilized, organic matter can accumulate in the top horizon and humic sandy soils develop. Based on their stability and depth of the sandy cover they correlate with Arenosols and Cambisols.

\section{Soils influenced by parent materials}

This major type combines shallow soils in which soil formation is greatly influenced by the nature of the parent material. Their profile development is limited by the shallow depth to the lithic contact and steep slope position and/or erosive parent material.

Humus-carbonate soils are highly eroded soils with remnants of the humus rich horizon and calcium carbonate close to the surface. Most of them satisfy the criteria of Cambisols or Calcisols.

Rendzinas develop on hard or weathered carbonate rich parent material and have organic matter-rich surface horizons. Based on the depth and kind of the parent rock they correlate with Leptosols or Cambisols.

Erubase and Ranker soils develop on carbonate free hard rock. Based on the depth, humification and base saturation of the topsoil they satisfy the Leptosols or Umbrisols criteria.

\section{Chernozems}

These are soils with high base saturation and thick, dark, mollic horizons. They commonly form on loess or loess-like parent material under grassland vegetation and are characterized by high biological activity. Their further classification and correlation is based on the colour of the mollic horizon, on the depth of the carbonate accumulation and possible influence of the groundwater.

Pseudomyceliar chernozems are characterized by fine secondary calcium carbonate at shallow depths and satisfy the WRB Chernozems criteria.

In leached chernozems calcium carbonate accumulates in the $\mathrm{C}$ horizon and often correlates these soils with Phaeozems. In a few locations the HSCS chernozems do not satisfy the colour requirements of the WRB Chernozems and correlate 
Table 1

Simplified key to the Reference Groups of the WRB, 1998 edition (DECKERS et al., 2001)

\begin{tabular}{|c|c|c|c|}
\hline 1 & Organic matter $>40 \mathrm{~cm}$ deep & Yes $\rightarrow$ & HISTOSOLS \\
\hline \multicolumn{4}{|c|}{$\downarrow$ no } \\
\hline 2 & Cyric horizon & Yes $\rightarrow$ & CRYOSOLS \\
\hline \multicolumn{4}{|c|}{$\downarrow$ no } \\
\hline 3 & Human modifications & Yes $\rightarrow$ & ANTHROSOLS \\
\hline \multicolumn{4}{|c|}{$\downarrow$ no } \\
\hline 4 & Depth $<25 \mathrm{~cm}$ & Yes $\rightarrow$ & LEPTOSOLS \\
\hline \multicolumn{4}{|c|}{$\downarrow$ no } \\
\hline 5 & $>35 \%$ clay vertic horizon & Yes $\rightarrow$ & VERTISOLS \\
\hline \multicolumn{4}{|c|}{$\downarrow$ no } \\
\hline 6 & Fluvic materials & Yes $\rightarrow$ & FLUVISOLS \\
\hline \multicolumn{4}{|c|}{$\downarrow$ no } \\
\hline 7 & Salic horizon & Yes $\rightarrow$ & SOLONCHAKS \\
\hline \multicolumn{4}{|c|}{$\downarrow$ no } \\
\hline 8 & Gleyic properties & Yes $\rightarrow$ & GLEYSOLS \\
\hline \multicolumn{4}{|c|}{$\downarrow$ no } \\
\hline 9 & Andic or vitric horizon & Yes $\rightarrow$ & ANDOSOLS \\
\hline \multicolumn{4}{|c|}{$\downarrow$ no } \\
\hline 10 & Spodic horizon & Yes $\rightarrow$ & PODZOLS \\
\hline \multicolumn{4}{|c|}{$\downarrow$ no } \\
\hline 11 & Plinthite or petroplinthite within $50 \mathrm{~cm}$ & Yes $\rightarrow$ & PLINTHOSOLS \\
\hline \multicolumn{4}{|c|}{$\downarrow$ no } \\
\hline 12 & Ferralic horizon & Yes $\rightarrow$ & FERRALSOLS \\
\hline \multicolumn{4}{|c|}{$\downarrow$ no } \\
\hline 13 & Natric horizon & Yes $\rightarrow$ & SOLONETZ \\
\hline \multicolumn{4}{|c|}{$\downarrow$ no } \\
\hline 14 & Abrupt textural change & Yes $\rightarrow$ & PLANOSOLS \\
\hline \multicolumn{4}{|c|}{$\downarrow$ no } \\
\hline 15 & Chernic or blackish mollic horizon & Yes $\rightarrow$ & CHERNOZEMS \\
\hline \multicolumn{4}{|c|}{$\downarrow$ no } \\
\hline 16 & Brownish mollic horizon and secondary $\mathrm{CaCO}_{3}$ & Yes $\rightarrow$ & KASTANOZEMS \\
\hline \multicolumn{4}{|c|}{$\downarrow$ no } \\
\hline 17 & Mollic horizon & Yes $\rightarrow$ & PHAEOZEMS \\
\hline & $\downarrow$ no & & \\
\hline
\end{tabular}


Table 1 continued

\begin{tabular}{|c|c|c|c|}
\hline 18 & Gypsic or petrogypsic horizon & \multirow[t]{2}{*}{ Yes $\rightarrow$} & \multirow[t]{2}{*}{ GYPSISOLS } \\
\hline & $\downarrow$ no & & \\
\hline 19 & Duric or petroduric horizon & \multirow[t]{2}{*}{ Yes $\rightarrow$} & \multirow[t]{2}{*}{ DURISOLS } \\
\hline & $\downarrow$ no & & \\
\hline & Calcic or petrocalcic horizon & \multirow{2}{*}{ Yes $\rightarrow$} & \multirow[t]{2}{*}{ CALCISOLS } \\
\hline & $\downarrow$ no & & \\
\hline & Argic horizon and albeluvic tonguing & \multirow[t]{2}{*}{ Yes $\rightarrow$} & \multirow[t]{2}{*}{ ALBELUVISOLS } \\
\hline & $\downarrow$ no & & \\
\hline & Argic horizon with $\mathrm{CEC}_{\mathrm{c}}>24, \mathrm{Al}_{\text {sat }}>60 \%$ & \multirow[t]{2}{*}{ Yes $\rightarrow$} & \multirow[t]{2}{*}{ ALISOLS } \\
\hline & $\downarrow$ no & & \\
\hline & Argic and nitic horizons & \multirow{2}{*}{ Yes $\rightarrow$} & \multirow[t]{2}{*}{ NITISOLS } \\
\hline & $\downarrow$ no & & \\
\hline & Argic horizon with $\mathrm{CEC}_{\mathrm{c}}<24, \mathrm{BS}<50 \%$ & \multirow[t]{2}{*}{ Yes $\rightarrow$} & \multirow[t]{2}{*}{ ACRISOLS } \\
\hline & $\downarrow$ no & & \\
\hline & Argic horizon with $\mathrm{CEC}_{\mathrm{c}}>24, \mathrm{BS}>50 \%$ & \multirow[t]{2}{*}{ Yes $\rightarrow$} & \multirow[t]{2}{*}{ LUVISOLS } \\
\hline & $\downarrow$ no & & \\
\hline & Argic horizon with $\mathrm{CEC}_{\mathrm{c}}<24, \mathrm{BS}>50 \%$ & \multirow[t]{2}{*}{ Yes $\rightarrow$} & \multirow[t]{2}{*}{ LIXISOLS } \\
\hline & $\downarrow$ no & & \\
\hline & Umbric horizon & \multirow[t]{2}{*}{ Yes $\rightarrow$} & \multirow[t]{2}{*}{ UMBRISOLS } \\
\hline & $\downarrow$ no & & \\
\hline & Cambic horizon & \multirow{2}{*}{ Yes $\rightarrow$} & \multirow[t]{2}{*}{ CAMBISOLS } \\
\hline & $\downarrow$ no & & \\
\hline & Coarse texture $>100 \mathrm{~cm}$ & \multirow[t]{2}{*}{ Yes $\rightarrow$} & \multirow[t]{2}{*}{ ARENOSOLS } \\
\hline & $\downarrow$ no & & \\
\hline & Other soils & $\rightarrow$ & REGOSOLS \\
\hline
\end{tabular}

"only" with the Kastanozems. Meadow chernozems are influenced by groundwater and correlate with Gleyic Chernozem.

Alluvial chernozems develop on alluvial sediments. Since fluvic is not among the qualifiers in WRB, the stratification between 50 and $100 \mathrm{~cm}$ cannot be indicated. Thus HSCS chernozem soils that have fluvic soil material between 25 and 50 $\mathrm{cm}$ correlate with Mollic Fluvisols.

\section{Brown forest soils}

These brown soils generally form under forest vegetation and are characterized by ochric (light coloured) surface horizons. This main type is a broad category that includes members without or with distinct subsurface horizons. 
Chernozem brown forest soils represent transitions with Chernozems and correlate with Luvic Chernozems.

Brown earths represent the classic leached Raman brown forest soils without a textural B horizon, that correlate with ERB Cambisols.

Brown forest soils with clay illuviation are the most common forest soils and correlate with Luvisols.

The accumulation horizon of most podzolic brown forest soils does not satisfy the criteria of the spodic diagnostic horizon, so these soils do not correlate with WRB Podzols but with low base saturation Luvisols or Umbrisols.

Stagnant brown forest soils have a slowly permeable clay accumulation horizon that correlates them with Stagnic Luvisols.

Banded brown forest soils developed in sandy parent material will correlate with Lamelli-Arenic Luvisols.

Acidic, non-podzolic brown forest soils are extremely acid, low base saturation soils without clay illuviation, placing them in Cambisols or Umbrisols.

\section{Salt affected soils}

These are soils with poor natural drainage that develop in the presence of soluble salts or with sodium as the dominant exchangeable cation. Their characteristics and limitations to plant growth depend on the amount, depth and composition of the salts.

Solonchaks are strongly saline soils with high concentration of "soluble salts". They develop in areas where evapotranspiration is considerably higher than the precipitation. Most of them correlate well with WRB Solonchaks.

Meadow solonetz soils have high sodium saturation and have typical columnar (natric) textural B horizons. Most of them satisfy the WRB Solonetz, those that have well-developed vertic horizon in the upper $1 \mathrm{~m}$ correlate with Vertisols.

Solonchak-solonetzes are transitional soils, while Steppe meadow solonetz soils are the ameliorated ones that often have a mollic horizon and correlate best with WRB Chernozems or Solonetz.

\section{Meadow soils}

These soils develop in depressions influenced by prolonged periods of water saturation in the presence of organic matter. They occur on various parent materials generally under grass vegetation.

Solonchak meadow soils and Solonetzic meadow soils are transitional soils with less influence of soluble soils or soluble salts occur in deeper horizons. Depending on the percent and composition of the salts and properties related to swelling clays they possibly correlate with Solonchaks, Cambisols or Vertisols.

The definition of typic meadow soils allows a broad range of soils to fit into the category. The major criterion is to show hydromorphic features at a shallow depth. Soils with high or low organic matter, clay or secondary carbonate might be members of the unit, making correlation at the type level very loose (MICHÉLI et al., 
2005). The possible correlation RGs include Phaeozems, Chernozems, Vertisols, Cambisols.

Peaty meadow soils have high organic matter accumulation but not enough to satisfy the histic horizon and Histosol definitions, putting these soils in the Chernozems or Phaeozems RGs. Chernozem meadow soils show characteristics of Chernozems with shallow groundwater influence, correlating them well with Gleyic Chernozems.

\section{Peat soils}

Peat soils have large accumulations of partially decomposed organic matter, developed under very wet conditions generally related to high groundwater levels. Sphagnum peats and meadow peat soils are both black and very dark brown and preserve recognizable remains of plant and satisfy the Histosols criteria. Ameliorated peats with greater organic matter decomposition may satisfy several WRB RGs allowing mollic or umbric horizons.

\section{Soils of swampy forests}

Soils of swampy forests are acid soils with moderate profile development exposed to long periods of groundwater saturation. They mostly correlate with Gleysols or Cambisols.

\section{Soils of alluvial and slope sediments}

These are young soils of periodically flooded areas and soils of slope sediments. They show stratification of the sediments rather than pedogenic horizons. Their characteristics and correlation depend on the nature and sequence of the sediments and time of soil formation after or between depositions.

Raw and humic alluvial soils correlate well with WRB Fluvisols. Soils of slope sediments mostly correlate with the Regosols of the WRB.

\section{Results}

The most common genetic horizons, according to the FAO guidelines for soil description (FAO, 1990) and the common WRB diagnostic horizons, properties and materials of the soil types of the HSCS are given in Table 2 together with the correlated WRB Reference Groups and common qualifiers.

The results are based on estimated properties according to the definitions of the taxonomic levels. From the table it is obvious that a one-to-one correlation based on the information content (definitions, limits) of the taxonomic units is not possible. For correlation of specific soils, records of field observation of morphological features and laboratory data are required. 


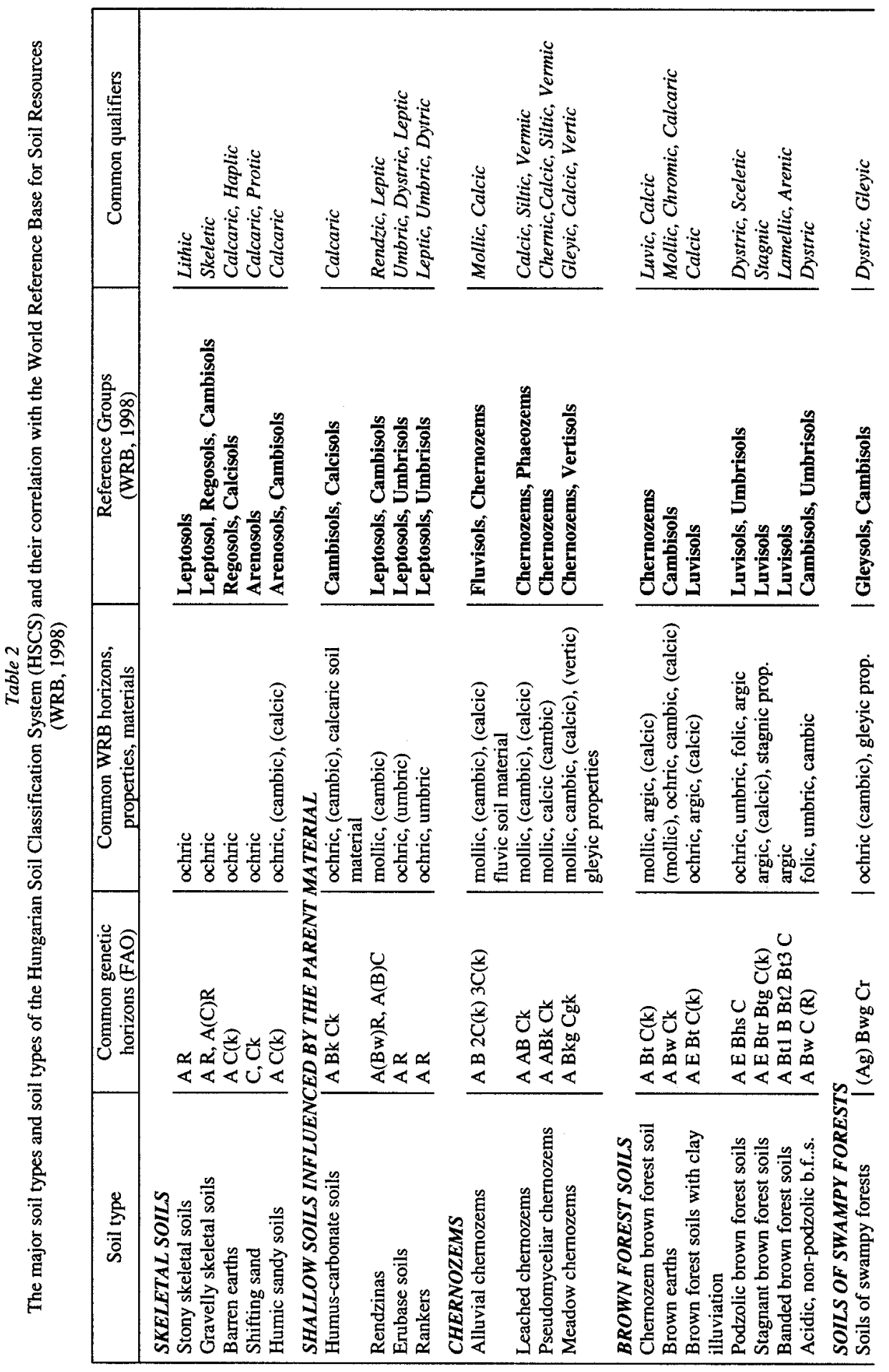




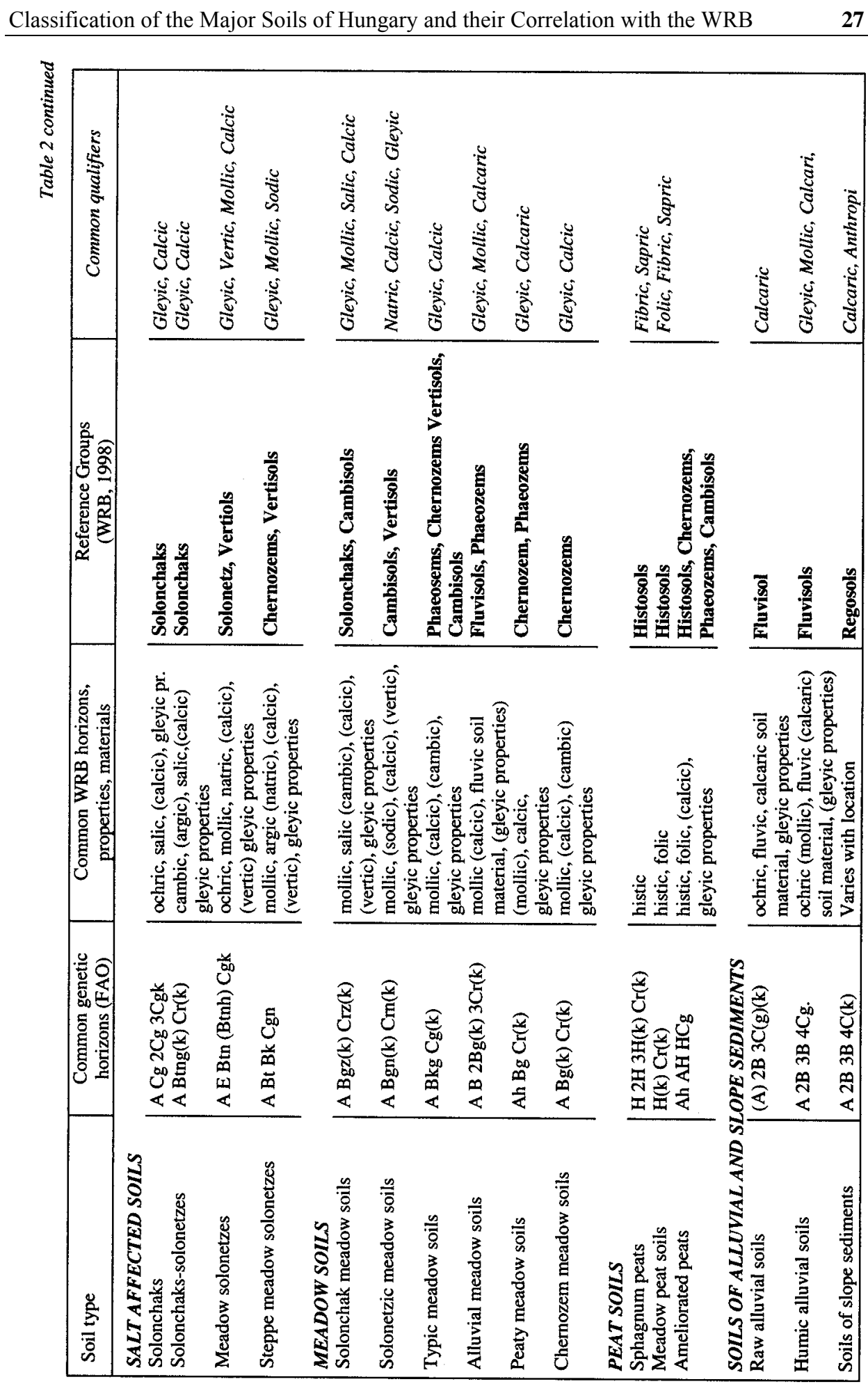


Key words: soil classification, WRB, Hungary, correlation

\section{References}

DECKERS, J. et al., 2001. World Reference Base for Soil Resources - in a nutshell. In: Soil Classification. (Eds.: MichÉLI, E. et al.) 71-79. European Soil Bureau Research Report. No. 7. ESB. Ispra.

FAO, 1990. Guidelines for Soil Description. $3^{\text {rd }}$ ed. FAO. Rome.

FAO/ISRIC/ISSS, 1998. World Reference Base for Soil Resources. World Soil Resources Report. No. 84. FAO. Rome.

MichÉLI, E. et al., 2005. Classification problems of high clay content soils. (In Hungarian) In: Talajvédelem. 278-281. Budapest.

Soil Survey Staff, 1996. Soil Taxonomy. USDA-SCS Agriculture Handbook No. 436. US Government Printing Office. Washington, D. C.

Stefanovits, P., 1963. The Soils of Hungary. $2^{\text {nd }}$ ed. (In Hungarian) Akadémiai Kiadó. Budapest.

SzABOLCS, I. (Ed.), 1966. Manual of Large-scale Soil Mapping. (In Hungarian) OMMI. Budapest.

VAN REEUWIJK, L. P., 1995. Procedures for Soil Analysis. $5^{\text {th }}$ edition. ISRIC Technical Paper No. 9. ISRIC. Wageningen, The Netherlands. 